\title{
PAX5 wt Allele
}

National Cancer Institute

\section{Source}

National Cancer Institute. PAX5 wt Allele. NCI Thesaurus. Code C52146.

Human PAX5 wild-type allele is located in the vicinity of 9p13 and is approximately $201 \mathrm{~kb}$ in length. This allele, which encodes paired box gene Pax-5 protein, is involved in transcriptional activation during B-cell differentiation, neural development and spermatogenesis. In some lymphomas, the expression of the wild-type allele is elevated as a result of a translocation $t(9 ; 14)(p 13 ; q 32)$. 